\title{
Haemorheological changes in patients with retinal vein occlusion after isovolaemic haemodilution
}

\author{
J Wiek, M Schade, M Wiederholt, H R Arntz, L L Hansen
}

\begin{abstract}
In 83 patients with central retinal vein occlusion and branch vein occlusion we measured the haematocrit (HCT), plasma viscosity (PV), red cell aggregation (RCA), red cell filterability (RCF) and apparent whole blood viscosity $(\mathrm{WBV})$. A control group $(n=41)$ was matched for sex, age, and cardiovascular risk factors. Measurements were performed before and after treatment with isovolaemic haemodilution (IHD). We found no significant differences between patients with retinal vein occlusion (RVO) and control subjects in haematocrit, plasma viscosity, red cell aggregation, and red cell filterability and no increased whole blood viscosity in the patient group. Patients with ischaemic retinal vein occlusion and non-ischaemic retinal vein occlusion did not show different haemorheological parameters either. After treatment with haemodilution, only the haematocrit and whole blood viscosity were significantly decreased, and there were no changes in plasma viscosity, red cell aggregation or red cell filterability.
\end{abstract}

Some studies ${ }^{1-4}$ have shown that impaired blood rheology might have a role in the pathogenesis of retinal vein occlusion (RVO). The authors reported an increased haematocrit and whole blood viscosity in patients with retinal vein occlusion $^{2}$ or ischaemic retinal vein occlusion..$^{13}$ In addition in all patients with retinal vein occlusion the plasma viscosity was found to be raised ${ }^{124}$ and red cell filterability to be decreased. ${ }^{4}$ So far no studies of red cell aggregation have been done in patients with retinal vein occlusion.

Several studies have stressed the role of haemorheology by demonstrating that isovolaemic haemodilution (IHD) is a beneficial for patients with this disease. ${ }^{5-9}$ However, some important questions remain unanswered:

(1) How do patients with retinal vein occlusion compare with subjects of the same age and sex with the same prevalence of cardiovascular risk factors in terms of haemorheology?

(2) Do basic haemorheological parameters differ in patients with different types of retinal vein occlusion (ischaemic versus non-ischaemic), as has been found by some authors? ${ }^{13}$

(3) Can the beneficial effects of haemodilution in the treatment of retinal vein occlusion be correlated with a higher blood fluidity?

We measured the basic rheological parameters haematocrit, plasma viscosity, red cell aggregation, red cell filterability, and also the apparent -whole blood viscosity in patients with central retinal vein occlusion (CRVO) and branch vein occlusion (RBVO) in comparison with a control group matched for sex, age, and cardiovascular risk factors without vascular diseases of the eye. In addition we determined these parameters in patients with retinal vein occlusion after treatment by isovolaemic haemodilution.

\section{Subjects and methods}

All patients with recent retinal vein occlusion (less than eight weeks' duration of symptoms) referred to the Eye Clinic, Klinikum Steglitz, Free University of Berlin, between July 1984 and December 1986 were considered for a prospective trial. Patients with systemic diseases such as congestive heart failure unresponsive to treatment, renal and respiratory insufficiency, and anaemia (haematocrit below $38 \%$ ) were excluded from the study. ${ }^{6810} \mathrm{We}$ included 66 patients older than 50 years of age and 17 patients of 30 to 50 years of age (Table 1). The patients of two randomised controlled studies on isovolaemic haemodilution ${ }^{810}$ were also included.

The control subjects were divided into two age and sex matched groups of 30 to 50 years and older than 50 years. The first group was recruited from healthy colleagues of our clinic. The older group was recruited from patients without vascular diseases of the eye who had to undergo surgery for cataract or retinal detachment. This group was matched for cardiovascular risk factors.

Every patient underwent a physical examination, electrocardiography (ECG), and chest $x$ ray, together with basic laboratory tests and measurement of fibrinogen. In addition the patients were submitted to a detailed ophthalmological examination, funduscopy, and fluorescein angiography.

We classified the retinal vein occlusions into ischaemic and non-ischaemic types. ${ }^{8-10}$ At least two of the following conditions had to be fulfilled to allow the diagnosis of an ischaemic central retinal vein occlusion: (1) Fluorescein angiogram: time for maximal venous filling ( $\left.t_{m v f}\right)$ $\geq 20$ s. (2) Capillary occlusion: area of $\geq 1$ papilla diameter (PD) and/or $\geq 10$ cotton-wool spots. (3) Visual acuity: $\leq 6 / 60$.

Table 1 Subdivision of patients

\begin{tabular}{llllll}
\hline Age & Type & Treatment & Total & Women & Men \\
\hline $30-50$ & CRVO & IHD & 17 & 10 & 7 \\
\hline$>50$ & RVO & IHD & 36 & 18 & 18 \\
& RBVO & IHD & 11 & 7 & 4 \\
CRVO & IHD & 25 & 11 & 14 \\
$>50$ & RVO & no IHD & 30 & 17 & 13 \\
& RBVO & no IHD & 17 & 8 & 9 \\
& CRVO & no IHD & 13 & 9 & 4 \\
\hline
\end{tabular}

$R V O=$ retinal vein occlusion. $R B V O=$ retinal branch vein occlusion. $C R V O=$ central retinal vein occlusion with and without isovolaemic haemodilution (IHD). 
A branch vein occlusion was regarded to be ischaemic if it had at least three cotton-wool spots and/or a capillary occlusion area of one PD or more. The procedure for isovolaemic haemodilution has been described elsewhere. ${ }^{689}$

As venous occlusion in younger patients may often be due to inflammatory changes in ophthalmic veins, ${ }^{11}$ all patients younger than 50 years were additionally treated with systemic steroids ( $75 \mathrm{mg}$ of prednisolone daily) for one week, with subsequent tapering over 3-5 weeks. Patients with ischaemic CRVO were photocoagulated to prevent neovascular glaucoma and retinal neovascularisation. ${ }^{69}$

\section{RHEOLOGICAL MEASUREMENTS}

The venous blood for rheological measurements was drawn from an antecubital vein without stasis and immediately collected into test tubes containing EDTA as anticoagulant.

The haematocrit was evaluated by centrifugation at $15000 \mathrm{~g}$ for five minutes (micromethod).

Plasma viscosity was measured at $37^{\circ} \mathrm{C}$ after centrifugation ( $3000 \mathrm{~g}$ for 10 minutes) with an Ubbelohde capillary viscosimeter. ${ }^{12}$ The measurement was repeated five times. The data are given in $\mathrm{cm}^{2} / \mathrm{s}=$ centistokes $(\mathrm{cSt})$.

The determination of the red cell aggregation was done with a Myrenne aggregometer ${ }^{13}$ with a natural (unchanged haematocrit) and with a standardised blood sample (haematocrit: $40 \%$ ). At first our investigations were done at a shear rate of $460 / \mathrm{s}$ for $10 \mathrm{~s}$ to disaggregate the blood and then measured at a stop of $0 / \mathrm{s}$. After a modification of the Myrenne aggregometer (modernisation to allow two different measurements) the blood was disaggregated at a rate of $600 / \mathrm{s}$ for $5 \mathrm{~s}$, and then red cell aggregation was measured at (1) a stop to $0 / \mathrm{s}$ and (2) after a reduction to $3 / \mathrm{s}$. The measurements of the new and the old method are not comparable. Values are without dimension.

For measuring the red cell filterability we used a Myrenne MF4 with nucleopore filters of $5 \mu \mathrm{m}$ pore diameter of one single batch. By this method it is possible to detect changes in red cell filterability in four of five stress models. ${ }^{14}$ The blood sample was washed twice in a special phosphate buffered human albumin solution and diluted with this buffer to a haematocrit of $4 \%$. Our results show the inital slope (initial rise of flow curve, after $10 \%$ of the blood sample has passed the nucleopore filter). We think that these early values are only mildly affected by clogging of the nucleopore filters with white blood cells. ${ }^{14}$ We measured two blood samples from each patient using new nucleopore filters for each measurement.

Apparent whole blood viscosity was measured at $37^{\circ} \mathrm{C}$ with a Wells-Brookfield cone plate microviscometer Model LVT's at shear rates of $230,115,46$, and $23 \mathrm{~s}^{-1}$ Measurements at lower shear rates $\left(11.5\right.$ and $\left.5.75 \mathrm{~s}^{-1}\right)$ were discarded, because they are less reliable. ${ }^{316}{ }^{17}$ We determined whole blood viscosity in a native blood sample and a standardised blood sample with a haematocrit of $40 \%$. All measurements were repeated twice. The data are given in $\mathrm{g} / \mathrm{cm} \times \mathrm{s}=$ centipose
(cP). Theoretically it should not be necessary to determine the whole blood viscosity, as the haematocrit, the plasma viscosity, the red cell aggregation, and the red cell filterability are the basic parameters of blood viscosity. Nevertheless, we evaluated whole blood viscosity to circumvent the uncertainties in the determination of red cell aggregation and red cell filterability by including an additional parameter and also to be able to compare our results with those of other authors, ${ }^{1-3}$ who relied mainly on whole blood viscosity.

The statistical variation of the results is expressed as the standard deviation about the mean. Student's $t$ test was used for comparison of two means. Significant differences were considered to be present with $\mathrm{p}<0.05$.

\section{Results}

Control subjects and patients over 50 years of age showed the same prevalence of cardiovascular risk factors. $55 \%$ of control subjects and $54 \%$ of the patients with retinal vein occlusion had at least two of the following risk factors: hyperten$\operatorname{sion}(>160 / 90 \mathrm{~mm} \mathrm{Hg})$, smoking, obesity, hyperlipoproteinaemia, cardiovascular diseases (for example, history of myocardial or cerebral infarction, angina pectoris, transient ischaemic attacks), diabetes mellitus.

\section{CONTROL GROUP}

Table 2 shows the results of haemorheological measurements in control subjects of 30-50 years and $>50$ years. Age distribution was similar in men and women. There were no age dependent differences in the haematocrit (HCT) within the groups of the same sex. However, women of both age groups had a significantly lower haematocrit than men. The plasma viscosity (PV) of men and women did not differ, but younger men had a lower plasma viscosity than older ones. The red cell aggregability (RCA) of women aged 30-50

Table 2 Rheological data of control subjects

\begin{tabular}{|c|c|c|c|c|c|}
\hline & & $F>50$ & $F 30-50$ & $M>50$ & M 30-50 \\
\hline $\begin{array}{l}\text { Age } \\
\text { (years) }\end{array}$ & $\begin{array}{l}\text { Mean } \\
\text { SD }\end{array}$ & $\begin{array}{r}72 \cdot 3 \\
8 \cdot 4\end{array}$ & $\begin{array}{r}39 \cdot 1 \\
7 \cdot 2\end{array}$ & $\begin{array}{r}65 \cdot 6 \\
9 \cdot 8\end{array}$ & $\begin{array}{r}41 \cdot 2 \\
6 \cdot 3\end{array}$ \\
\hline \multirow{2}{*}{$\begin{array}{l}\text { HCT } \\
(\%)\end{array}$} & $\begin{array}{l}\mathbf{n} \\
\text { Mean }\end{array}$ & $\begin{array}{l}9 \\
41 \cdot 8\end{array}$ & $\begin{array}{l}12 \\
41 \cdot 6\end{array}$ & $\begin{array}{l}10 \\
46 \cdot 4^{\star \star}\end{array}$ & $\begin{array}{l}10 \\
44 \cdot 3^{\star \star}\end{array}$ \\
\hline & $\begin{array}{l}\mathrm{SD} \\
\mathrm{n}\end{array}$ & $\begin{array}{l}2 \cdot 3 \\
9\end{array}$ & $12^{1 \cdot 8}$ & $\begin{array}{l}3 \cdot 6 \\
10\end{array}$ & $\begin{array}{l}2 \cdot 8 \\
10\end{array}$ \\
\hline $\begin{array}{l}\text { PV } \\
\text { (cSt) }\end{array}$ & $\begin{array}{l}\text { Mean } \\
\text { SD }\end{array}$ & $\begin{array}{l}1 \cdot 35 \\
0 \cdot 11\end{array}$ & $\begin{array}{l}1.29 \\
0.05\end{array}$ & $\begin{array}{l}1.40+ \\
0.1\end{array}$ & $\begin{array}{l}1.28 \\
0.06\end{array}$ \\
\hline RCA & $\begin{array}{l}\text { n } \\
\text { Mean } \\
\text { SD }\end{array}$ & $\begin{array}{c}9 \\
18 \cdot 1 \\
5 \cdot 2 \\
4\end{array}$ & $\begin{array}{c}12 \\
13 \cdot 4^{\star} \\
2 \cdot 2 \\
8\end{array}$ & $\begin{array}{c}10 \\
17 \cdot 1 \\
3 \cdot 1 \\
6\end{array}$ & $\begin{array}{c}10 \\
18 \cdot 8 \\
3 \cdot 9 \\
8\end{array}$ \\
\hline RCF & $\begin{array}{l}\text { Mean } \\
\text { SD } \\
\text { n }\end{array}$ & $\begin{array}{c}27 \cdot 4 \\
5 \cdot 5 \\
6\end{array}$ & $\begin{array}{c}21 \cdot 6 \\
8 \cdot 0 \\
12\end{array}$ & $\begin{array}{c}24 \cdot 6 \\
9 \cdot 4 \\
10\end{array}$ & $\begin{array}{c}25 \cdot 0 \\
8 \cdot 6 \\
7\end{array}$ \\
\hline \multirow{5}{*}{$\begin{array}{l}\text { WBV } \\
230 / s \\
\text { (cP) } \\
\text { WBV } \\
23 / s\end{array}$} & $\begin{array}{l}\text { Mean } \\
\text { SD }\end{array}$ & $\begin{array}{l}4 \cdot 6 \\
0.5\end{array}$ & $\begin{array}{l}4 \cdot 0++ \\
0 \cdot 3\end{array}$ & $\begin{array}{l}5 \cdot 0 \\
0.8\end{array}$ & $\begin{array}{l}4 \cdot 7^{\star \star \star} \\
0 \cdot 3\end{array}$ \\
\hline & n & 9 & 12 & $10^{\circ}$ & 10 \\
\hline & Mean & 6.9 & $6 \cdot 1$ & $8 \cdot 0^{\star}$ & $7 \cdot 0^{\star \star \star}$ \\
\hline & SD & $1 \cdot 4$ & 0.9 & $1 \cdot 3$ & $1 \cdot 0$ \\
\hline & $\mathbf{n}$ & & 12 & 10 & 10 \\
\hline
\end{tabular}

Mean values of age, haematocrit (HCT), plasma viscosity (PV) red cell aggregation (RCA), red cell filterability (RCF), and whole blood viscosity (WBV $-230 / \mathrm{s}$ and $23 / \mathrm{s}$ ) depending on age ( $>50$, 30-50) and $\operatorname{sex}(F, M)$. Significant differences are given between groups of same age and different $\operatorname{sex}\left({ }^{\star} p<0.05, \star \star p<0.01\right.$

$\left.{ }_{\star \star \star} p<0.001\right)$ and groups of same sex and different age $(+p<0.05$, $++\mathrm{p}<0.01,+++\mathrm{p}<0.001)$. RCA was measured after disaggregation with a shear rate of $460 / \mathrm{s}$ and a stop to $0 / \mathrm{s}$. 
years was significantly lower than in men of the same age. There were no age related differences within the groups of men and women. Table 2 gives the results of the old method before modification of the aggregometer; all other tables show the results of the new method after a stop to $0 / \mathrm{s}$. Red cell filterability was not dependent on age or sex. Measurements of whole blood viscosity revealed a higher fluidity in women aged $30-50$ years than in the group of $>50$ years at a high shear rate, probably depending on a slightly lower plasma viscosity and a decreased red cell aggregation in this age group. Correspondingly, men of the younger age group in comparison with the younger women had higher whole blood viscosity at the shear rates of 230/s and 23/s, Men over 50 had higher whole blood viscosity only at the shear rate of $23 / \mathrm{s}$. These differences may be due to the higher haematocrit of men. Our tables show the results of the natural (unchanged haematocrit) blood samples.

\section{PATIENTS WITH RETINAL VEIN OCCLUSION}

Table 3 shows the mean values of rheological data in patients with retinal vein occlusion divided by age and sex. We found significant differences between patients and control subjects only in whole blood viscosity at a shear rate of $230 / \mathrm{s}$. Women $>50$ years and men of 30-50 years had lower whole blood viscosities than corres-

Table 3 Rheological data of patients with RVO dependent on age and sex

\begin{tabular}{|c|c|c|c|c|c|c|c|}
\hline & & \multicolumn{3}{|c|}{ Women } & \multicolumn{3}{|l|}{ Men } \\
\hline & & Mean & $S D$ & $n$ & Mean & $S D$ & $n$ \\
\hline Age & $\begin{array}{l}\text { RVO 30-50 } \\
\text { RVO }>50\end{array}$ & $\begin{array}{l}44: 8 \\
68 \cdot 3\end{array}$ & $\begin{array}{l}4.7 \\
8.4\end{array}$ & $\begin{array}{l}10 \\
35\end{array}$ & $\begin{array}{l}44 \cdot 9 \\
63 \cdot 0\end{array}$ & $\begin{array}{l}2.6 \\
8.9\end{array}$ & $\begin{array}{r}7 \\
31\end{array}$ \\
\hline HCT & RVO 30-50 & 42.5 & 3.0 & 11 & 43.9 & $2 \cdot 3$ & 8 \\
\hline $\begin{array}{l}\text { (\%) } \\
\text { PV }\end{array}$ & $\begin{array}{l}\text { RVO }>50 \\
\text { RVO } 30-50\end{array}$ & $\begin{array}{ll}41 \cdot 7 \\
1.30\end{array}$ & $\begin{array}{l}2 \cdot 3 \\
0.08\end{array}$ & $\begin{array}{l}35 \\
11\end{array}$ & $\begin{array}{c}44 \cdot 8 \\
1 \cdot 32\end{array}$ & $\begin{array}{l}3.4 \\
0.08\end{array}$ & $\begin{array}{r}31 \\
8\end{array}$ \\
\hline (cSt) & RVO $>50$ & 1.35 & 0.08 & 35 & 1.35 & 0.09 & 31 \\
\hline RCÁ & RVO 30-50 & $6 \cdot 3$ & 1.1 & 7 & $6 \cdot 3$ & 1.5 & 5 \\
\hline & $\begin{array}{l}\text { RVO }>5 \\
\text { PYO } 30\end{array}$ & $\begin{array}{r}8 \cdot 0 \\
0.7\end{array}$ & 1.7 & 18 & $7 \cdot 2$ & $\begin{array}{l}1.9 \\
2.2\end{array}$ & 17 \\
\hline $\mathrm{KCF}$ & $\begin{array}{l}\text { RVO 30-50 } \\
\text { RVO >5 }\end{array}$ & $\begin{array}{l}20 \cdot 7 \\
23 \cdot 9\end{array}$ & $\begin{array}{l}6.9 \\
5.5\end{array}$ & 32 & $\begin{array}{l}24 \cdot 1 \\
24 \cdot 1\end{array}$ & 7.0 & 28 \\
\hline $\begin{array}{l}\text { WBV } \\
230 / s\end{array}$ & $\begin{array}{l}\text { RVO 30-50 } \\
\text { RVO }>50\end{array}$ & $\begin{array}{l}4 \cdot 2 \\
4 \cdot 1^{\star \star \star}\end{array}$ & $\begin{array}{l}0.5 \\
0.4\end{array}$ & $\begin{array}{l}11 \\
34\end{array}$ & $\begin{array}{l}4 \cdot 3^{\star} \\
4 \cdot 6\end{array}$ & $\begin{array}{l}0.2 \\
0.5\end{array}$ & $\begin{array}{r}8 \\
30\end{array}$ \\
\hline $\begin{array}{l}\text { CP) } \\
\text { WB }\end{array}$ & & & & & & & \\
\hline $23 / \mathrm{s}$ & 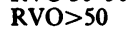 & & 0.8 & 34 & 7 . & 1 . & 0 \\
\hline
\end{tabular}

$30-50$ and $>50$ refers to the age group. Significant

differences $\left({ }^{\star} p<0.05,{ }^{\star \star} p<0.01\right)$ refer to corresponding control subjects. For other abbreviations see Table 2 . RCA was measured with the new method (shear rate of $600 / \mathrm{s}$ and then stop to $0 / \mathrm{s}$.)

Table 4 Rheological data of patients over 50 years of age with $R V O$ dependent on the type of occlusion

\begin{tabular}{|c|c|c|c|c|c|c|c|}
\hline \multirow{2}{*}{$\cdot$} & & \multicolumn{3}{|c|}{ Women $>50$} & \multicolumn{3}{|c|}{$M e n>50$} \\
\hline & & Mean & & $n$ & Mean & $S D$ & $n$ \\
\hline Age & RVO i & $\begin{array}{l}65 \cdot 5 \\
69.9\end{array}$ & $\begin{array}{l}7 \cdot 4 \\
8 \cdot 7\end{array}$ & 13 & $\begin{array}{l}60 \cdot 2 \\
66 \cdot 4\end{array}$ & $\begin{array}{l}8.5 \\
8.4\end{array}$ & $\begin{array}{l}17 \\
14\end{array}$ \\
\hline HCT & RVO i & $41 \cdot 1$ & 1.8 & 13 & $44 \cdot 4$ & $3 \cdot 6$ & 17 \\
\hline$(\%)$ & RVO ni & $42 \cdot 0$ & $2 \cdot 5$ & 22 & $45 \cdot 2$ & $3 \cdot 1$ & 14 \\
\hline PV & RVO $\mathrm{i}$ & $1 \cdot 32$ & 0.09 & 13 & $1 \cdot 33$ & 0.08 & 17 \\
\hline (cSt) & RVO ni & $1 \cdot 36$ & 0.07 & 22 & 1.37 & 0.09 & 14 \\
\hline RCÁ & RVOi & 6.9 & 1.5 & $\begin{array}{r}5 \\
13\end{array}$ & $\begin{array}{l}6.9 \\
7.7\end{array}$ & 1.8 & 10 \\
\hline & RVO ni & 8.4 & 1.7 & 13 & $7 \cdot 7$ & $2 \cdot 2$ & 7 \\
\hline RCF & RVO $\mathrm{i}$ & 23.9 & 5.9 & 11 & $23 \cdot 5$ & $8 \cdot 1$ & 17 \\
\hline & RVO ni & $23 \cdot 8$ & $5 \cdot 4$ & 21 & $25 \cdot 1$ & $5 \cdot 0$ & 11 \\
\hline WBV & RVO i & $4 \cdot 1$ & 0.3 & 13 & 4.5 & 0.4 & 17 \\
\hline $230 / \mathrm{s}$ & RVO ni & $4 \cdot 2$ & 0.4 & 21 & $4 \cdot 7$ & 0.5 & 13 \\
\hline WBV & RVO i & 6.0 & $0 \cdot 7$ & 13 & $7 \cdot 2$ & $1 \cdot 3$ & 17 \\
\hline $23 / \mathrm{s}$ & RVO ni & 6.5 & 0.9 & 21 & $7 \cdot \overline{5}$ & 1.0 & 13 \\
\hline
\end{tabular}

$\mathrm{i}=$ Ischaemic, $\mathrm{ni}=$ Non-ischaemic. For other abbreviations see Table 2. ponding control groups. When dividing retinal vein occlusion into ischaemic and non-ischaemic types in the group older than 50 (the number of the group aged $30-50$ years of age was too small to make this division), we found no significant differences between the two types in any of our measurements (Table 4). Nor did we find significant differences between patients with retinal branch vein occlusion and patients with central retinal vein occlusion.

ISOVOLAEMIC HAEMODILUTION

Tables 5 and 6 and Fig 1 depict the results of patients with retinal vein occlusion before and after haemodilution. All four groups show significant differences in haematocrit and whole blood viscosity (230/s and 23/s) before and after haemodilution, but no changes of plasma viscosity, red cell aggregation, or red cell filterability.

\section{Discussion}

The interpretation of basic rheological parameters in patients with disturbed retinal circulation requires carefully selected and matched control subjects. In addition, one has to avoid methodological problems, especially in the determination of red cell aggregation and red cell filterability. Our patients and control subjects were properly matched by sex, age, and, most important, cardiovascular risk factors. Nevertheless it seems useful to compare the values obtained from our control subjects with measurements provided by other studies. ${ }^{18}$ As expected, the haematocrit values confirmed the independence of age and the dependence on sex, as other authors have shown. ${ }^{18} 19$

The plasma viscosity proved to be independent of sex, but men over 50 had a higher plasma

Table 5 Rheological data of women with RVO before and after isovolaemic haemodilution

\begin{tabular}{|c|c|c|c|c|c|c|c|}
\hline & \multicolumn{3}{|c|}{ Before IHD } & \multicolumn{3}{|c|}{ After IHD } & \multirow[b]{2}{*}{$p \leqslant$} \\
\hline & Mean & $S D$ & $n$ & Mean & $S D$ & $n$ & \\
\hline $\begin{array}{l}\text { Women } 30-50 \\
\text { HCT } \\
\text { PV } \\
\text { RCA } \\
\text { RCF } \\
\text { Women }<50\end{array}$ & $\begin{array}{c}42 \cdot 1 \\
1 \cdot 29 \\
6 \cdot 2 \\
21 \cdot 9\end{array}$ & $\begin{array}{l}3.7 \\
0.1 \\
0.9 \\
6.8\end{array}$ & $\begin{array}{l}7 \\
7 \\
4 \\
6\end{array}$ & $\begin{array}{c}36 \cdot 1 \\
1.32 \\
5.9 \\
23 \cdot 6\end{array}$ & $\begin{array}{l}3 \cdot 6 \\
0 \cdot 11 \\
0.9 \\
5 \cdot 7\end{array}$ & $\begin{array}{l}6 \\
6 \\
3 \\
5\end{array}$ & $\begin{array}{l}0.05 \\
\text { ns } \\
- \\
\text { ns }\end{array}$ \\
\hline $\begin{array}{l}\text { HCT } \\
\text { PV } \\
\text { RCA } \\
\text { RCF }\end{array}$ & $\begin{array}{c}41 \cdot 8 \\
1 \cdot 34 \\
7 \cdot 8 \\
21 \cdot 7\end{array}$ & $\begin{array}{l}2 \cdot 3 \\
0.09 \\
1.9 \\
4.9\end{array}$ & $\begin{array}{r}18 \\
18 \\
7 \\
16\end{array}$ & $\begin{array}{c}35 \cdot 8 \\
1 \cdot 31 \\
7 \cdot 0 \\
20 \cdot 0\end{array}$ & $\begin{array}{l}4 \cdot 8 \\
0 \cdot 09 \\
2 \cdot 1 \\
7 \cdot 6\end{array}$ & $\begin{array}{r}17 \\
17 \\
6 \\
16\end{array}$ & $\begin{array}{l}0 \cdot 01 \\
\text { ns } \\
\text { ns } \\
\text { ns }\end{array}$ \\
\hline
\end{tabular}

For abbreviations see Table 2.

Table 6 Rheological data of men with RVO before and after isovolaemic haemodilution

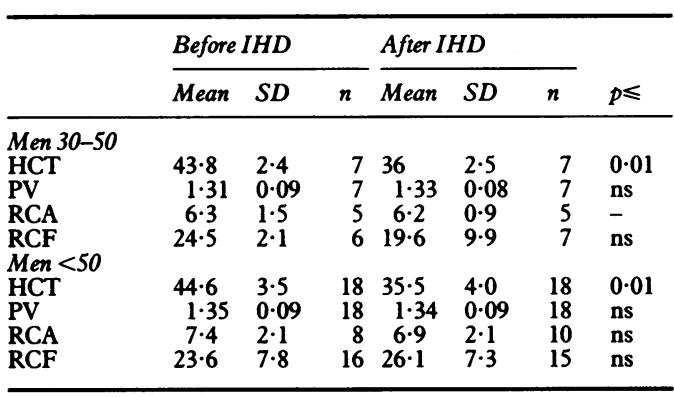

For abbreviations see Table 2. 


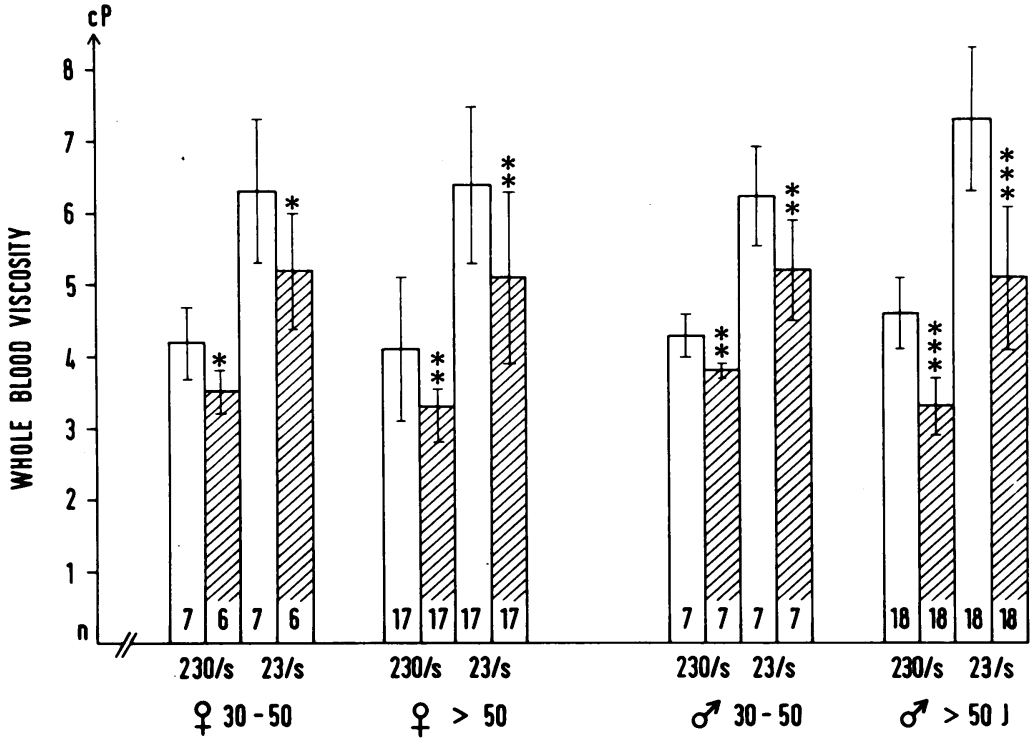

Figure 1 Decrease of whole blood viscosity after haemodilution (hatched bars) in men and women in the two different age groups. $230 /$ s and $23 / s=$ shear rates. ${ }^{\star} p<0.05,{ }^{\star} p<0.01$, $\star \star \star p<0.001$. vs $36 \%$ in non-ischaemic RVO), which might account for a higher haematocrit. Correspondingly the same authors found higher whole blood viscosity in patients with ischaemic retinal vein occlusion. Peduzzi et al $^{4}$ found increased whole blood viscosity in all patients with retinal vein occlusion at a shear rate of $23 / \mathrm{s}$. We have no explanation for these differences in our results, as Peduzzi used the same methods as we did. McGrath et $a l^{2}$ found higher whole blood viscosity in $53 \%$ of their patients with retinal vein occlusion, but they used considerably lower shear rates for their investigations, so that their results are not comparable with ours.

As to the plasma viscosity, we could not confirm the results of earlier investigations, ${ }^{1-3}$ as we did not find raised plasma viscosities in RVO patients. Dodson et $a l^{26}$ found raised plasma viscosities in patients with retinal vein occlusion only in comparison with controls without hypertension. It is known that cardiovascular risk factors can lead to an increase of plasma viscosity and other rheological parameters. ${ }^{121}$ This may explain why our patients with retinal vein occlusion had similar values of plasma viscosity as control subjects, as we had almost the same prevalence of at least two cardiovascular risk factors (about 55\%) in both groups. If one compares our numerical values of plasma viscosity with those of a healthy reference population without cardiovascular risk factors, as investigated by Jung et $a l^{18}$ the plasma viscosity of our groups seems to be raised. So it is not surprising that people with retinal vein occlusion and risk factors have increased plasma viscosity in comparison with controls without risk factors.

Until now there have been no investigations into red cell aggregation in patients with retinal vein occlusion. Because the method was changed we unfortunately have only small numbers of comparable patients and control subjects, but between these small groups we found no significant differences.

Peduzzi et $a l^{4}$ reported decreased red cell filterability in patients with retinal vein occlusion. However, they used the method of whole blood filtration, ${ }^{27}$ which can no longer be regarded as a reliable method for red cell filtration. ${ }^{25}$

Haemodilution by definition decreases the haematocrit and hence should lower whole blood viscosity. This could be demonstrated in all haemodiluted patients. The increased fluidity of the whole blood was induced only by reduction of the haematocrit. All other basic rheological parameters remained unchanged by haemodilution. Kiesewetter et $a l^{28}$ have shown, albeit using different methods, that red cell filterability was increased and red cell aggregation reduced by a combination of iso- and hypervolaemic haemodilution in patients with peripheral arterial occlusive disease. This was not confirmed by Heinen $e t a l$ in patients with retinal vein occlusion, who reported no change of red cell filterability after haemodilution and an increase of red cell filterability after hypervolaemic haemodilution. Our finding of an unchanged plasma viscosity is supported by both studies. ${ }^{728}$

In conclusion, our study has demonstrated that patients with retinal vein occlusion do not have a different haemorheological profile when not take into account the distribution of $m e n$ and women. Ring et al did not state the sex distribution, and Trope et al had a higher percentage of men than women in the ischaemic group $(65 \%$ 
compared with control subjects matched for age, sex, and risk factors. Furthermore, the determination of plasma viscosity, red cell aggregation, red cell filterability, and haematocrit does not help in the clinically important differential diagnosis of ischaemic versus non-ischaemic retinal vein occlusion. But the measurement of the haematocrit remains necessary, as this value is important for monitoring the isovolaemic haemodilution. Lack of measurable systemic rheological abnormalities does not exclude local changes of fluidity in retinal vein occlusion, which becomes obvious by fluorescein angiography..$^{8-10}$ Furthermore, haemodilution improves the visual outcome of many patients with retinal vein occlusion ${ }^{679}{ }^{10}$ by improving the retinal microcirculation, as has been shown by a decrease of time of maximal venous filling. ${ }^{8-10}$ These beneficial effects of haemodilution may be mediated by a decreased blood viscosity.

This study was supported by the Deutsche Forschungsgemeinschaft (grant Ga 225/1-6).

1 Ring CP, Pearson TC, Sanders MD, Wetherley-Mein G. Viscosity and retinal vein thrombosis. Brf Ophthalmol 1976; 60: $397-410$

2 McGrath MA, Wechsler F, Hunyor ABL, Penny R. Systemic factors contributory to retinal vein occlusion. Arch Inter Med 1978; 138: 216-20.

3 Trope GE, Lowe GDO, Meardle BM, et al. Abnormal blood viscosity and haemostasis in long-standing retinal vein occlusion. Brf Ophthalmol 1983; 67: 137-42.

4 Peduzzi M, Debbis A, Guerrierri F, Bolzani R. Abnormal blood viscosity and filterability in retinal vein occlusion. Clin Hemorheol 1984; 4: 555-61.

5 Wiederholt M, Leonhardt H, Schmid-Schönbein H, Hager H. Die Behandlung von Zentralvenenverschlüssen und Die Behandlung von Zentralvenenverschlüssen und Zentralarterienverschlüssen mit isovolämischer Hämo-

6 Hansen LL, Danisevskis P, Arntz HR, Hövener G, Wiederholt $M$. A randomised prospective study on treatment of central retinal vein occlusion by isovolaemic haemodilution. $\mathrm{Br} \mathcal{F}$ Ophthalmol 1985; 69: 108-16.

7 Heinen A, Brunner R, Hossmann V, Konen W, Roll K, Warer $T$. Different types of therapy having hemorheological effects in patients with impairment of blood supply to the retina (randomised double blind study). Clin Hemorheol 1986; 6: 61-71.

8 Hansen LL, Wiek J, Wiederholt M. A randomised prospective study of treatment of non-ischaemic central retinal vein occlusion by isovolaemic haemodilution. Br $\mathcal{F}$ Ophthalmol 1989; 73: 895-899.
9 Hansen LL, Wiek J, Schade M, Müller-Stolzenburg N, Wiederholt $M$. Effects and compatibility of isovolaemic haemodilution in the treatment of ischaemic and nonischaemic central retinal vein occlusion. Ophthalmologic 1989; 199: 90-9.

10 Hansen LL, Wiek J, Arntz HR. Randomisierte Studie zur Wirkung der isovolämischen Hämodilution bei retinalen Venenastverschlüssen. Fortschr Ophthalmol 1988; 85: $514-6$.

11 Hayreh SS. So-called central retinal vein occlusion. I. Pathogenesis, terminology, clinical features. Ophthalmologica 1976; 172: 1-13.

12 Leonhardt $\mathrm{H}$, Uthoff A, Uthoff C. Vollblut- und Plasmaviskosität bei koronaren Risikofaktoren. Klin Wochenschr 1977 55: 481-5.

13 Kiesewetter H, Radtke H, Schneider R, Mussler K, Scheffler A, Schmid-Schöbein H. Das Mini-Erythrozyten-Aggregometer: Ein neues Gerät zur schnellen Quantifizierung des Ausmasses der Erythrozytenaggregation. Biomed Tech (Berlin) 1982; 27: 209-13.

14 Seiffge D. Correlation of different methods to determine red blood cell deformability. Clin Hemorheol 1984; 4: 263-73.

15 Wells RE, Denton R, Merrill EW. Measurement of viscosity of biologic fluids by cone plate viscometer. 7 Lab Clin Med 1961; 57: 646.

16 Ernst E, Matrai A. Rotationsviskometer in Hämorheologie. Arztl Lab 1982; 28: 33-8.

17 Inglis TCM, Carson PJ, Stuart J. Clinical measurement of whole-blood viscosity at low-shear rates. Clin Hemorheol whole-blood viscosi $167-77$.

18 Jung F, Kiesewetter H, Roggenkamp HG, et al. Bestimmung der Referenzbereiche rheologischer Parameter: Studie an 643 zufällig ausgewählten Probanden im Kreis Aachen. Klin Wochenschr 1986; 64: 375-81.

19 Shahidi NT. Androgens and erythropoesis. $N$ Engl $f \mathrm{Med}$ 1973; 269: 72 .

20 Lowe GDO, Forbes CD. Blood rheology and thrombosis. Clin Haematol 1981; 10: 343-367.

21 Letcher RL, Chien S, Pickering TG, Sewley JE, Laragh JH Direct relationship between blood pressure and blood viscosity in normal and hypertensive subjects. $A m \mathcal{F} \mathrm{Med}$ 1981; 70: 1195-9.

22 Chien S. Principles and techniques for assessing erythrocyte deformability Blood Cells 1978; 3: 71-76.

23 Meiselman HJ. Measures of blood rheology and erythrocyte mechanics. In: Codelett GR. Meiselman HJ, Brooks DE mechanics. In: Codelett GR. Meiselman HJ, Brooks DE, Springer, 1980: 75-80.

24 Dormandy J. Clinical relevance of filtration tests. In: Dormandy J, ed Red cell deformability and filterability. Den Haag: Nijhoff, 1983: 176-82.

25 Chien S. Specific recommendations for filtration tests. In Dormandy J, ed. Red cell deformability and filterability. Den Haag: Nijhoff, 1983: 216.

26 Dodson PM, Galton DJ, Hamilton AM, Blach RK. Retinal vein occlusion and the prevalence of lipoprotein abnormalities. Br $\mathcal{F}$ Ophthalmol 1982; 66: 161-4.

27 Reid HL, Barnes A J, Lock PJ, Dormandy JA, Dormandy TL: A simple method for measuring erythrocytes deformability. J Clin Pathol 1976; 29: 855-8.

28 Kiesewetter H, Jung F, Lazar H, Roggenkamp HG, Leipnitz $\mathrm{G}, \mathrm{Kiehl} \mathbf{R}$. Hematocrit as a risk for vascular disease. Klin Wochenschr 1986; 64: 974-8. 